DOI: $10.15421 / 272010$

УДК 629.7 (091) (477) «19/20»

В. С. Савчук

Дніпровський національний університет імені Олеся Гончара, м. Дніпро, Україна

\title{
АВІАЦІЙНИЙ ТИЖДЕНЬ НА ПІВДЕННОРОСІЙСЬКІЙ ОБЛАСНІЙ СІЛЬСЬКОГОСПОДАРСЬКІЙ, ПРОМИСЛОВІЙ І КУСТАРНІЙ ВИСТАВЦІ 1910 р. У КАТЕРИНОСЛАВІ: ПРОЕКТ, ЯКИЙ НЕ ЗДІЙСНИВСЯ
}

E-mail: varfolomey44@gmail.com

ORCID ID: https://orcid.org/0000-0002-6324-7567

Анотація. Мета статті - 3'ясувати малодосліджені події повітроплавного та авіаційного життя Катеринослава в контексті світового розвитку авіації, визначити події, які привели до виникнення проекту проведення авіаційного тижня у Катеринославі та перебіг процесу його підготовки. Для досягнення мети дослідження використано аналітико-синтетичній, історико-хронологічний, порівняльно-історичний, логічний методи, метод синхронізації. Висвітлено події світового та вітчизняного рівня, які передували появі цього проекту. Визначено історіографію дослідження, доведено, що поряд 3 незначною кількістю публікацій, які розглядають розвиток авіації у Катеринославі, вони мають більше публіцистичний, ніж науковий характер. Зазначено ініціюючу роль цих публікацій для подальших досліджень. 3'ясовано вплив Південноросійської обласної сільськогосподарської, промислової і кустарної виставки, яка відбулася у Катеринославі з липня 1910 р. по 10 жовтня 1910 р., на зародження ідеї проведення авіаційного тижня у Катеринославі та перебіг його підготовки. Висвітлено невідомі раніше факти активної реакції авіаторів, виробників літаків та авіаційних установ і об’єднань на можливість участі у Південноросійській обласній сільськогосподарській, промисловій і кустарній виставці. Наведено численні факти відповідних пропозицій щодо участі у виставці і доведено, що така активність сприяла висуненню проекту проведення міжнародного авіаційного тижня під час виставки. Показано, що планований авіаційний тиждень дійсно мав би міжнародний характер, міг відбутися за участю відомих авіаторів-пілотів (зокрема таких знаних у світі як С. І. Уточкін, Е. Жільбер), на ньому був би представлений широкий спектр конструкцій, здатних підняти людину і вантажі у повітря. Серед них повітряні кулі, дирижаблі, літаки різноманітних конструкцій тощо. Доведено, що планований міжнародний авіаційний тиждень такого масштабу був би першим в Україні і другим у Російській імперії. Здійснення цього проекту могло б зробити цю виставку непересічною історичною подією в розвитку авіаційної справи в Україні. Визначено причини, які в останній момент спонукали Розпорядчий комітет виставки відмовитися від реалізації цього проекту. Висловлено думку, що незважаючи на те, що даний проект не було здійснено, $є$ всі підстави для твердження про його значимість для розвитку авіаційної справи в Україні.

Ключові слова: Катеринослав, Південноросійська обласна сільськогосподарська, промислова і кустарна виставка, авіаційний тиждень, проект, авіаційна спільнота, фінансування, авіатори, літаки, дирижаблі. 


\title{
V.S. Savchuk
}

Oles’ Honchar Dnipro National University, Dnipro, Ukraine

\section{AVIATION WEEK AT THE SOUTH RUSSIAN REGIONAL AGRICULTURAL, INDUSTRIAL AND HANDICRAFT EXHIBITION IN 1910 IN KATERYNOSLAV: A PROJECT THAT HAS NOT BEEN COMPLETED}

\begin{abstract}
The purpose of the article is to consider the little-learned events of Ekaterinoslav's aviation and aviation life in the context of world aviation development, to identify the events that led to the emergence of the aviation week project in Ekaterinoslav and the process of its preparation. Analytical-synthetic, historical-chronological, comparative-historical, logical methods, synchronization method were used to achieve the purpose of the study. The events of the world and domestic level, which preceded the appearance of this project, are covered. The historiography of the study has been studied, and it has been proved that, along with a small number of publications examining the development of aviation in Ekaterinoslav, they are more journalistic than scientific. The initiating role of these publications for further research is noted.

The influence of the South Russian regional agricultural, industrial and handicraft exhibition, which took place in Yekaterinoslav from July 1, 1910 to October 10, 1910, on the origin of the idea of holding an aviation week in Yekaterinoslav and the process of its preparation were clarified. The previously unknown facts of the active reaction of aviators, aircraft manufacturers and aviation institutions and associations on the possibility of participation in the South Russian regional agricultural, industrial and handicraft exhibition are covered. Numerous facts of relevant proposals on participation in the exhibition are presented and it is proved that such activity contributed to the nomination of the project for holding an international aviation week during the exhibition. It is shown that the planned aviation week could indeed have an international character, would take place with the participation of well-known aviator pilots (in particular, such well-known in the world as S.I. Utochkin, E. Gilbert), a wide range of designs capable of lift a person and loads into the air. Among them are balloons, airships, planes of various designs and the like. It is noted that the planned international aviation week of this scale would be the first in Ukraine and the second in the Russian Empire. The implementation of this project could have made this exhibition a historic event in the development of aviation business in Ukraine. The reasons which prompted the exhibition's steering committee to abandon the implementation of this project were identified. The opinion was expressed that despite the fact that this project was not implemented, there is every reason to state its importance for the development of aviation business in Ukraine
\end{abstract}

Keywords: Yekaterinoslav, South Russian Regional Agricultural, Industrial and Handicraft Exhibition, Aviation Week, project, aviation community, financing, aviators, airplanes, airships.

Вступ. Почавши свого часу винахідницьку діяльність 3 планерів, американські авіаконструктори та авіатори брати Уілбер і Орвілл Райт, володарі велосипедної майстерні в м. Дейтон, запровадили вертикальний руль, поперечні рулі-елерони та виміряли підйомну силу крил за допомогою продування у винайденій ними аеродинамічній трубі. Побудований братами Райт планер був 
добре керованим і міг триматися у повітрі близько хвилини. У 1903 р. брати Райт поставили на планер невеликий бензиновий двигун, який виготовили самі, у своїй майстерні. 14 грудня 1903 р. Уілбер Райт здійснив перший політ на літаку 3 двигуном внутрішнього згоряння, пролетівши 32 м. 17 грудня дальність польоту досягла 260 м, тривалість - 59 секунд. Це були перші польоти у світі. До братів Райт ще жоден аероплан не міг піднятися у повітря.

Спроби створення літака були і в Російській імперії. У цьому зв'язку згадаємо літак капітана Можайського, вихідця з України, який створив у період 3 1882 по 1885 pp. повномасштабну конструкцію літака, злет якого досі $\epsilon$ суперечливим 3 точки зору не тільки зарубіжних, але й ряду радянських та російських істориків техніки.

У будь-якому разі перший політ братів Райт викликав бурхливий розвиток, як тоді говорили, повітроплавання та швидке поширення авіаційних ідей у суспільстві. Здійнявся авіаційний бум і його перебіг відбувався різними шляхами: польоти в містах і перельоти між містами, які здійснювалися заради випробовування нових моделей літаків, покращення їх льотних якостей, встановлення нових рекордів тощо; демонстраційні польоти у населених пунктах, які були спрямовані на творення суспільної думки щодо необхідності підтримки нового технічного напряму та необхідності освоєння повітряного простору; створення нових моделей різного призначення як для цивільного, так і для військового застосування, теоретичне осмислення конструкторської думки та розробка відповідних теоретичних засад літакобудування тощо.

Зрозуміло, що Катеринослав був також втягнутий в орбіту цього процесу. Але про авіаційні події у Катеринославі до останнього часу було мало відомо. Та й кількість таких публікацій була обмежена. Серед тих, хто писав про повітроплавання та авіаційні події у Катеринославі (в першу чергу про польоти, які відбувалися за участі пілотів 3 інших міст) зазначимо публікації С. Борздухи, О. Невмержицької, М. Чабана, які з'явилися у ряді періодичних засобів масової інформації [5; 8; 20]. Недоліком цих публікацій $є$ те, що в них майже відсутні посилання на відповідні джерела і це обмежує їх сферу використання та достовірність. У той же час цінність цих публікацій безперечна, оскільки вони привернули і привертають увагу до маловідомих сторінок «повітроплавного» життя Катеринослава, які, безсумнівно, необхідно досліджувати в загальному контексті.

«Повітроплавне» життя Катеринослава не було звужене тільки до демонстраційних польотів та аматорських дій любителів повітроплавання, що доводить, між іншим, дослідження Н. М. Кушлакової [6]. Випала й інша досить цікава інформація про діяльність у Катеринославі колишніх авіаторів вже на іншому, зокрема політичному поприщі і т. п. Ретельне вивчення історії авіації у Катеринославі виявило ще один фактично маловідомий і невивчений епізод 3 вітчизняної авіаційної історії, а саме: спробу організації міжнародного авіаційного тижня у Катеринославі.

Метою дослідження $є$ виявлення джерел з авіаційної історії Катеринослава, з'ясування подій, які привели до виникнення проекту проведення міжнародного авіаційного тижня у Катеринославі, перебіг процесу підготовки цього заходу, його можливостей та причин нездійсненності цього проекту. Предмет дослідження проект проведення міжнародного авіаційного тижня у Катеринославі 1910 р..

В дослідженні були використані різноманітні джерела: історіографічні 3 історії розвитку вітчизняної авіації, розвитку інженерної справи на 
Катеринославщині, такі першоджерела, як преса періоду, що вивчався, та інші. В нагоді стали також інтернет-ресурси.

\section{Результати і обговорення}

«Повітроплавна» історія Катеринослава, за історіографічними джерелами, можливо, починається 3 демонстрації у місті діючої моделі металевого дирижабля винахідника 3 Ростова Григорія Кирилова [5; 8]. Передбачалося керування винайденого Кириловим аеростата за допомогою часового механізму. На жаль, проект цей не був здійснений. Спроба автора з'ясувати, хто ж такий Кирилов поки що привела лише до виникнення розходження 3 даними про Г. Кирилова, про які йшла мова вище. Повідомлення з Катеринослава в газеті «Русское слово» від 22 (09) січня 1910 р. суперечить даним, наведеним у публікаціях [5; 8]. У ньому повідомляється, що «местным (виокремлено мною - B. C.) инженером Кирилловым изобретен дирижабль, цеппелиновского типа, отличающийся от последнего особым устройством крыльев. Постройка дирижабля Кириллова обойдется около 5000 руб. Изобретатель, при огромном стечении публики, демонстрировал модель своего изобретения. Опыты прошли удачно» [4].

У 1906 р. в Київському політехнічному інституті з'явився палкий прихильник авіаційної справи професор Микола Борисович Делоне, який 4 грудня 1908 р. прочитав (замість захворілого М. Є. Жуковського) лекцію «Про повітроплавання» на засіданні механічного гуртка КПІ [15]. Надалі 3 публічними лекціями про повітроплавання він їздив по різних містах, побувавши 3 такою лекцією й у Катеринославі. На хвилі резонансу від цієї лекції студенти Катеринославського вищого гірничого училища, як вказано в ряді джерел [5; 8; 20], навіть почали збирати гроші на побудову планера за кресленнями М. Б. Делоне. Сам факт читання такої лекції у Катеринославі сумніву не викликає, але потребує уточнення дата. На жаль, автор публікації не наводить посилання на джерело інформації. Надалі у Катеринославському вищому гірничому училищі було створено повітроплавний гурток, точну дату початку діяльності якого (1 травня 1910 р.) наводить С. Борздуха [5]. Керівником повітроплавного гуртка був відомий катеринославський професор Петро Михайлович Леонтовський [10]. В одній із сучасних місцевих публікацій повідомляється навіть сума, яку пожертвував професор на створення планера (250 крб) та день, коли на Артилерійській площі відбувся перший політ сконструйованого гуртківцями планера (2 червня 1910 р.). Отже, цей день, мабуть, можна вважати першим «повітроплавальним» польотом у Катеринославі.

Цей політ було здійснено напередодні знаменитої Південноросійської обласної сільськогосподарської, промислової і кустарної виставки, яка відбулася у Катеринославі $з 1$ липня 1910 р. по 10 жовтня 1910 р. Слід зазначити, що район дії виставки охоплював п'ять губерній (Катеринославська, Полтавська, Харківська, Херсонська, Таврійська) та дві області (Донська та Кубанська). Ї̈і значення вийшло далеко за «регіональні межі, набувши не тільки всеросійського, а й міжнародного характеру, ставши яскравим прикладом стрімкого соціально-економічного розвитку регіону на рубежі XIX-XX століть» [21, p. 248].

Політ, безперечно, був сильним стимулом того, що Розпорядчий комітет виставки дійшов думки про можливість організації так званого «міжнародного авіаційного тижня». Акцентую саме на такій назві, тому що задум був дійсно значним. На ті часи в різних країнах вже проводилися так звані «міжнародні 
авіаційні тижні», на яких відбувалися різнопланові змагання на встановлення різноманітних авіаційних рекордів. Тому зупинюся на перебігу подій, які могли завершитися катеринославським «міжнародним авіаційним тижнем».

У квітні 1910 р. «группа студентов Горного института, члены кружка воздухоплавания: Мешко, Чуюн и Есманский предлагают комитету (з організації виставки - B. C.) свои услуги по организации воздухоплавательного подотдела выставки, причем изготовление моделей аэропланов, аэростатов и планеров и заведывание ими берут на себя на таких условиях: постройка модели из соснового дерева - 50 р., размер модели от 2-3 арш. Некоторые модели будут иметь резиновый двигатель и могут совершать полеты на расстояние нескольких сажен. Аэростаты, наполненные водородом, могут быть приготовлены по особому соглашению. Помимо этого, группа аэронавтов предлагает услуги по чтению лекций по аэростатике и аэродинамике и демонстрирование картин волшебного фонаря и синематографа, опытов и полетов моделей» [3, с. 5].

До комітету з підготовки і проведення виставки почали надходити все нові й нові пропозиції, що підпадали під діяльність пропонованого повітроплавного підвідділу. Так, імператорський всеросійський аероклуб запропонував Розпорядчому комітету «демонстрировать во время выставки дирижабль» [Там само]. Враховуючи значну вартість дирижабля, клуб висунув пропозицію про пропорційний (приблизно 2:1) розподіл витрат на придбання дирижабля та відшкодування витрат за рахунок платних польотів на ньому під час виставки. Польоти протягом двох тижнів повинен був здійснювати авіатор Шабський зі своїм помічником.

Катеринославський авіатор Краузе зі свого боку висунув пропозицію щодо демонстрування пропонованого ним аероплану під час виставки, але зажадав монопольного права на демонстрування польотів [Там само]. Очікуючи на пропозиції від інших авіаторів, Розпорядчий комітет довгий час не приймав 3 цього питання рішення. Тим не менш через деякий час газети повідомили, що «отделу авиации, по-видимому, предполагается отвести самое почетное место: переговоры с Краузе закончены - ему предоставлено 50 кв. саж. на выставочной площади... Краузе приобретает для полетов аэроплан Блерио» [11, с. 4].

Паралельно відбувалися перемовини з С. І. Уточкіним, який телеграмою повідомив комітет, що його уповноважений виїздить до Катеринослава для проведення перемовин.

Надійшла також пропозиція від Французького товариства розповсюдження авіаційного спорту і організації демонстрування повітроплавних апаратів щодо надання ним послуг «по запрошенню відомих авіаторів на виставку» [12, с. 4]. Комітет запланував вже місце на виставковій площі для демонстрування та збереження аеропланів. Лишилося ще вирішити питання звідки будуть робити розбіг аероплани, хоча, як писали в газеті, «для Уточкина, который подымается иногда перпендикулярно, это не имеет значения» [Там само].

Зазначимо ще ряд пропозицій для участі у повітроплавній діяльності на виставці. Зокрема, зі своєю пропозицією до Розпорядчого комітету звернувся перший в Російській імперії авіаційний завод першого російського товариства повітроплавання, пропонуючи вже в середині червня представити на виставку аероплан, причому «завод гарантирует успешность полета аэроплана» [15, с. 3]. Фабрика Кемпа 3 Майнца запропонувала «экспонировать биплан системы

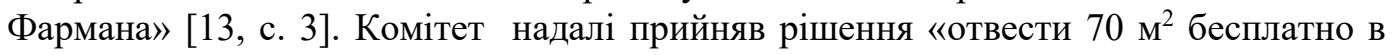


инженерно-строительном отделе для фабрики Кемпа в Майнце, экспонирующей биплан системы Фармана» $[15$, с. 3].

Продовжували надходити нові повітроплавні пропозиції. 3 Москви надійшла пропозиція влаштувати під час виставки польоти на кулі-балоні з пілотом та можливістю підйому на ній трьох пасажирів [17, с. 3]. 3'явилося також повідомлення, що «Киевское общество воздухоплавания в целях популяризации авиации через своего члена В. С. Меха просит распорядительный комитет разрешить обществу устроить в Екатеринославе во время выставки платный полет на аэроплане системы Блерио. Будет летать инженер Гейне за плату в 3000 руб. в день или 4500 руб. за 2 дня» [18, с. 3].

Імператорське московське технічне товариство (точніша назва: Московське відділення Імператорського російського технічного товариства. - B. C.) також висловило бажання взяти участь у роботі відділу авіатики. Серед пропозицій, що надходили до виставкового комітету, за різними джерелами, були й такі: свою участь в авіаційному тижні запропонували Євстафьєв 3 моделлю літака, «пілот повітряної кулі Симон з Копенгагена» та інші. Достеменно відомо, що Свстаф'єв демонстрував свою модель на виставці.

У пресі активно обговорювалося питання про те, як треба зорганізувати авіаційний тиждень, зазначалося, що «надо сделать так, чтобы авиационная неделя превратилась не в частно предпринимательское дело... А учитывая огромную общественную важность развития нового направления в технике нельзя ограничиться только полетами» [1, с. 3]. «Самым лучшим было бы если бы выставочный комитет сам устроил так называемую неделю или даже несколько недель авиации с состязаниями на скорость, продолжительность, высоту полетов и т. п. Назначение более или менее крупных призов послужило бы достаточным средством привлечения русских и заграничных авиаторов» [Там само].

Сама можливість влаштувати авіаційний тиждень під час проведення Південноросійської обласної сільськогосподарської, промислової і кустарної виставки була новаторською ідеєю, яка тільки почала втілюватися в Російській імперії. Нагадаємо, що перший авіаційний тиждень у Російській імперії був проведений у Петербурзі з 25 квітня (8 травня) по 2 (15) травня 1910 р., якраз під час підготовки до виставки у Катеринославі. Він мав назву «Неделя авиации на большой приз города Петербурга за совокупность полетов в течение всей недели» $\mathrm{i}$ став міжнародним. У ньому взяли участь як авіатори Російськой імперії, так і закордонні авіатори.

Тому ідея провести відповідний авіаційний тиждень у Катеринославі знайшла підтримку серед громадськості міста. Як зазначалося в одній з публікацій того часу, «Авиатика ... “гвоздь”, аэроплан - мечта носится в воздухе... И считаясь с современной психикой большинства невольно приходится остановиться на «воздухоплавательном» проекте. Согласно ему, предполагается выставочный комитет ассигнует на призы 100000 франков, принимает на себя расходы по устройству мест для «воздушных машин», для зрителей... Все эти расходы могут окупиться, если полеты посетит 120000 зрителей. Объявляется воздухоплавательный сезон, публикуются «призы». Со всех концов мира «слетаются» знаменитые авиаторы, и, если допустить, что первым условием успеха выставки является многолюдство, то невольно приходится согласиться с тем, что проект заслуживает самого глубокого внимания» [12, с. 4].

Спочатку все складалося на користь здійснення цього проекту та проведення міжнародного тижня авіації. 
11 травня 1910 р. на засіданні Розпорядчого комітету виставки за доповіддю авіаційної комісії відбулися палкі дискусії про проведення авіаційного тижня, наслідком яких став позитивний результат щодо його проведення. Як повідомляли газети, «большинством 2 голосов комитет постановил: ассигновать 5000 руб. на устройство аэродрома и 100000 франков на приз за свободные полеты» [14, с. 3]. Але була й жорстка опозиція: «Председатель остался при особом мнении, заявив, что при значительном риске, он считает невозможным тратить из земского бюджета такой суммы на предприятие, не входящее в задачи выставки» [Там само]. Питання було відкладене. Але наприкінці засідання комітету знову повернулися «к вопросу об авиатике, предложив такую резолюцию: оставить открытым вопрос об устройстве авиационной недели на выставке до 1 июля и затем, в том случае, если расходы по выставке окажутся непокрытыми платой за места, совсем отказаться от ее устройства. Предложение это собранием было принято» [Там само]. Пророчими виявилися слова журналіста, який так прокоментував це рішення: «...и таким образом авиатика, можно сказать, погребена заблаговременно» [Там само].

Це рішення фактично «засушило» проведення авіаційного тижня. Коли в день відкриття виставки (1 липня 1910 р.) до нього повернулися чи не в останній раз, Розпорядчий комітет заявив, що питання про авіаційний тиждень відкладається $[9$, c. 2]. I фактично до нього більше не поверталися.

Виникає питання: чи дійсно проект був безнадійним? Не розглядаючи його 3 точки зору фінансової спроможності, зупинимося на науково-технічних та інформаційно-популяризаційних можливостях планованого авіаційного тижня. Розглянемо його складові

Серед тих авіаторів, які вели перемовини про їхню участь у авіаційному тижні, були й всесвітньо відомі пілоти, такі як С. І. Уточкін та Е. Жільбер. Ім'я C. I. Уточкіна добре у нас відоме, тому зупинюся лише на короткій характеристиці французького авіатора Ежена Жільбера.

Е. Жільбер (1889-1918) почав свою спортивно-технічну кар'єру 3 автомобілізму. Вже у підлітковому віці (3 12 років) він брав в участь у різноманітних автопробігах. Надалі працював випробувачем, брав участь у мотогонках, став відомим спортсменом. 31908 р. захопився авіаційною справою. Закінчив у 1910 р. льотну школу. Надалі служив у французькій армії військовим пілотом. Після демобілізації працював «рекламним» пілотом на одній 3 моторобудівних фірм. Після початку Першої світової війни, як військовий пілот, брав участь у повітряних боях проти Німеччини. Набув слави повітряного аса. Два останні роки свого життя працював випробувачем нових літаків. Загинув під час випробувального польоту у 1918 р. Нагороджений орденом Почесного Легіону, іншими нагородами Франції. Лицар Почесного Легіону. Площа одного 3 міст Франції, де проживала родина Е. Жільбера, носить його ім'я [2].

Крім авіаторів Уточкіна і Жільбера, подавали заявки на участь в авіаційному тижні й інші відомі пілоти. Зокрема пілот Київського товариства повітроплавання інженер Ф. Л. Гейне, один з ініціаторів створення. куренівського аеродрому у Києві.

Серед виробників літаків, які подавали заявки на участь у авіаційному тижні, відмітимо перший в Російській імперії авіаційний завод Першого російського товариства повітроплавання, який отримав офіцйний дозвіл Міністерства торгівлі і промисловості на пуск заводу 15 червня 1910 р. [7, с. 2] i був офіційно відкритий 28 червня того самого року. Першими серійними літаками, 
які були розроблені і випущені на цьому заводі у 1910 р., стали біплан «Росія-А» (модифікований «Фарман») та моноплан «Росія-Б» [19].

Біплан «Росія-А», розроблений, за одними даними, на основі конструкції літака «Фарман» [19, с. 58-60], за іншими - це гібрид французьких літаків «Фарман-3» і «Соммер» [22]. Відомо також, що він був виготовлений вже до травня 1910 р. а офіційно випробуваний 2 серпня 1910 р. Саме цей літак під час пропозиції, зробленої заводом Розпорядчому комітету Південноросійської обласної сільськогосподарської, промислової і кустарної виставки, у 1910 р. випускався на заводі. Отже, можна висловити припущення, що саме його завод i мав намір продемонструвати на авіаційному тижні у Катеринославі.

Таким чином, на виставці могли зійтися літаки таких моделей: «Фарман» (Німеччина, Майнц), «Росія-А» (Санкт-Петербург), «Блеріо» (Київське товариство повітроплавання) та інші.

Звертає на себе увагу й те, що на виставці мали бути представлені конструкції різних засобів повітроплавання: повітряні кулі, дирижаблі, літаки. Тобто широкий спектр різноманітних конструкцій, здатних підняти людину i вантажі у повітря.

\section{Висновки}

На авіаційному тижні 1910 р. у Катеринославі в разі його проведення були б представлені різноманітні засоби повітроплавання, у польотах взяли б участь відомі вітчизняні і закордонні авіатори, відбулася б демонстрація різноманітних моделей літаків, у тому числі й перших літаків Російської імперії і т. п. Все зазначене складало комплекс, який, безперечно, став би окрасою планованого авіаційного тижня, що назавжди увійшов би в історію вітчизняної авіації.

Планований міжнародний авіаційний тиждень такого масштабу був би першим в Україні і можливо другим у Російській імперії. Але Розпорядчий комітет виставки, під тиском місцевого самоврядування, високопосадовці якого переймалися економічними ризиками проведення такого тижня, не наважилися на крок, який би міг зробити цю виставку історичною подією в розвитку авіаційної справи в Україні і Російській імперії в цілому.

Тим не менш вперше проведена реконструкція процесу підготовки міжнародного авіаційного тижня у Катеринославі, з'ясування комплексу планованих заходів, засобів повітроплавання, які мали бути представленими на авіаційному тижні, складу авіаторів - учасників планованого авіаційного тижня дає всі підстави для твердження про прогресивний розвиток вітчизняної авіаційної справи у загальносвітовому науково-технічному річищі.

\section{References}

1. About aviation at the Ekaterinoslav exhibition (1910). Yuzhnaya Zarya, no. 1180, April 30, p. 3 (in Russian).

2. Arrival in Odessa of the legendary French pilot Gilbert. URL: https://odessitua.com/articles/20306-pribytie-v-odessu-legendarnogo-francuzskogopilota-zhilbera.html

3. Aviation in Yekaterinoslav (1910). Yuzhnaya Zarya, no. 1173, April 22, p. 5 (in Russian).

4. Ballooning (1910). Russkoye slovo, January 22 (09) (in Russian). 
5. Borzduha S. Pages of the history of aviation of the Ekaterinoslav region. URL: http://www.aviajournal.com/arhiv/2004/02/05.html

6. Kushlakova N. M. (2016). Science-and-technology about the industrial regions of Ukraine (1890 - 1917). Pavlograd, Art-Synthesis-T, 2016, 588 p. (in Ukranian).

7. Maltinsky B. M. (2003). From the first airplanes to air defense missiles. The history of the state enterprise «Leningrad Northern Plant». St. Petersburg, Sudostroyeniye - 312 p. (in Russian).

8. Nevmerzhitska O. Students-miners want to fly! URL: https://dp.vgorode.ua/news/dosuh y eda/127842

9. Opening of the South Russian exhibition in Yekaterinoslav on July 1, 1910 (1910). Yuzhnaya Zarya, no. 1230, July 1, p. 2 (in Russian).

10. Pavlovsky I. F. (1913). First supplement to the «Brief Biographical Dictionary of Scientists and Writers of the Poltava Province from the Half of the 18th Century». Poltava, pp. 23-25 (in Russian).

11. South Russian exhibition in Yekaterinoslav. Aviatics (1910). Yuzhnaya Zarya, no. 1175, April 24, p. 4 (in Russian).

12. South Russian exhibition in Yekaterinoslav. Aviatics (1910). Yuzhnaya Zarya, no. 1178, April 28, p. 4 (in Russian).

13. South Russian exhibition in Yekaterinoslav. Aviatics (1910). Yuzhnaya Zarya, no. 1184, May 5, p. 3 (in Russian).

14. South Russian exhibition in Yekaterinoslav (1910): Manager Committee meeting. Yuzhnaya Zarya, no. 1192, May 14, p. 3 (in Russian).

15. South Russian exhibition in Yekaterinoslav (1910). Yuzhnaya Zarya, no. 1201, May 25, p. 2 (in Russian).

16. Tatarchuk V. V. (2014). Repeated siding of the Kiev Polytechnic Institute (19081915). History of Science and Technology, no. 5, pp. 111-128 (in Russian).

17. Chronicle of the exhibition. (1910). Yuzhnaya Zarya, no. 1238, July 11, p. 3 (in Russian).

18. Chronicle of the exhibition (1910). Yuzhnaya Zarya, no. 1241, July 14, p. 3. (in Russian).

19. Shavrov, V. B. (1985). The history of aircraft designs in the USSR until 1938. Ed. $3^{\text {rd }}$, Moskow, Mashinostroyeniye, 752 p. (in Russian).

20. Chaban M. P. Flights of Sergey Utochkin. URL: https://gorod.dp.ua/news/112906

21. Changli V. I. (2012/2013). South Russian regional agricultural, industrial and handicraft exhibition in 1910 in Ekaterinoslav (coverage in the local press). Prydniprov'ya: historical and local studies, no. 11, pp. 245-248 (in Ukranian).

22. Zasypkin Yu. V., Kostyrchenko G. V., Kuzmin Yu. V., Ostapenko Yu. A., Simonov A.

A., Sobolev D. A. (2011). History of the domestic aircraft industry. Series aircraft construction, 1910-2010. Ed. by D. A. Sobolev, Moskow, Russian Aviation Society (RUSAVIA), 432 p. (in Russian).

Received 28.01.2020.

Accepted 12.02.2020 